\title{
Necessity or opportunity? Government size, tax policy, corruption, and implications for entrepreneurship
}

\author{
David B. Audretsch • Maksim Belitski • \\ Farzana Chowdhury (D) Sameeksha Desai
}

Accepted: 13 April 2021 / Published online: 22 June 2021

(C) The Author(s) 2021

Abstract Government size, corruption, and tax policy can influence allocation towards necessity or opportunity-driven entrepreneurship. Using a comparative multi-source sample across 52 countries during 2005-2015, we apply a mixed-process estimation of the simultaneously unrelated system of equations and unpack these heterogeneous and complex effects. Interestingly, our results show that the influence of tax policy and corruption on necessity and opportunity entrepreneurship depends on government size. Our results hold for numerous robustness analyses.

Plain English summary Institutions matter for the choice of opportunity and necessity-driven entrepreneurship. Government size, the level of corruption,

The authors contributed equally to this work.

D. B. Audretsch · S. Desai

School of Public and Environmental Affairs, Indiana University, Bloomington, IN 47405, USA

D. B. Audretsch

e-mail: daudrets@indiana.edu

S. Desai

e-mail: desai@indiana.edu

\section{Belitski}

IGS-Groupe, University of Reading and ICD Business School, Rue Alexandre Parodi 12, 75010 Paris, France

e-mail: mbelitski@groupe-igs.fr

F. Chowdhury $(\bowtie)$

Department of Management and Marketing, Durham University

Business School, University of Durham, Durham, UK

e-mail: farzana.chowdhury@durham.ac.uk

e-mail: farza.chowdhury@gmail.com and tax policy directly affect entrepreneurs' motivation and incentives. We study 52 countries during 2005-2015 to find out to what extent tax rate, corruption, and a range of government expenditure change the allocation of necessity and opportunity entrepreneurship. Our main implications are for (1) Research: Formal and informal institutions need to be considered when studying entrepreneurship allocation, particularly in an emerging and developing country context. Results suggest that the impact of the same institutional settings and informal institutions such as corruption on necessity and opportunity entrepreneurship is not uniform in size and scope and have different magnitude. The effect of government expenditure on necessity and opportunity entrepreneurship is not ubiquitous. (2) Management: The broader institutional context affects allocation of entrepreneurship, and potential entrepreneurs can consider how corruption in particular can affect them. (3) Policy: Policymakerscan measure the extent to which opportunity and necessity entrepreneurship are likely to change, when they make changes to tax policy, resources for public spending, and take anti-corruption measures.

Keywords Government size · Tax rate · Necessity entrepreneurship · Opportunity entrepreneurship . Corruption

JEL Classifications $\mathrm{L} 26 \cdot \mathrm{H} 20 \cdot \mathrm{H} 50$ 


\section{Introduction}

Many countries have seen an increase in government size and taxes (Mueller, 2004; Tanzi \& Schuknecht, 2000). A robust stream of primarily economics research has examined the influence of government size on economic development and social welfare (see Alesina et al., 2004; Asimakopoulos \& Karavias, 2016; Barro, 1990) and entrepreneurship (Nyström, 2008; Audretsch \& Lehmann, 2017; Audretsch et al., 2006, 2019a, b). However, there is still a paucity of knowledge in identifying how these components interact with each other to influence different types of entrepreneurial activity (van der Zwan et al., 2016). A critical gap remains in the literature: how government size and institutional environment influence different types of entrepreneurship. To address this gap in the literature, we ask the following question: How do government size, tax policy, and corruption influence entrepreneurial allocation towards necessity or opportunity entrepreneurship?. This question is an in-depth look into how government, the regulatory environment of a country, and broader institutions can influenceentrepreneurial climate. Additionally, the combination of policies and the institutional climate produces the pull and push factors as the two opposing forces that contribute todifferent types of entrepreneurial activity (opportunity and necessity entrepreneurship) in diverse institutional contexts (Audretsch et al., 2019a, b; Block et al., 2015; Block \& Sandner, 2009; Nikolaev et al., 2018; Stenholm et al., 2013; van der Zwan et al., 2016; Welter et al., 2019).

Different types of entrepreneurial activities are essential to consider because the quality of entrepreneurship dictates the technological change, structural transformation, and economic development (Amorós et al., 2019; Belda \& Cabrer-Borrás, 2018; van der Zwan et al., 2016). Compared to necessity entrepreneurship, opportunity entrepreneurship occurs when entrepreneurs have other work options but still decide to pursue entrepreneurship (Acs et al., 2008; Vivarelli, 2004, 2013). While entrepreneurship contributes to economic development and social welfare, not all entrepreneurship activity contributes equally. Therefore, determining the context that promotes desired entrepreneurial activity is essential (Baumol, 1990; Baumol \& Strom, 2007; Fredström et al., 2020).

The overall economic environment and governmental policies play a crucial role and govern these opposing forces (Fairlie et al., 2011). Opportunity entrepreneurs may spend less and delay investments during high taxation and recessions, while they are also more likely to start a business when tax policy and government size are more conducive; necessity entrepreneurs, on the other hand, are forced out of the labor force and into entrepreneurship because of adverse economic conditions (Shiller, 2017).

Government size is a critical component to consider because larger government may mean a greater capacity to provide services and fund public governance activities. These supports could encourage entrepreneurship activities by providing safety nets to offset risks, highquality inputs related to labor, and efficient capital markets. Larger government could also mean more inadequate governance if it allows overreach or inefficiency (see Afonso et al., 2005; Hauner \& Kyobe, 2010), which could discourage entrepreneurship activities by complicating the business environment and putting entrepreneurs at risk for predatory behavior by government agents.

Along with government size, tax policy directly affects entrepreneurs' incentives to enter the market (Friedman et al., 2000). Government is a core dimension of any country's regulatory setup, and taxes provide revenues for public spending. Taxes, government size, and corruption are important to consider together becausegovernment requires tax revenue to operate and maintainservices, which corruption can affect (see Belitski et al., 2016; O’Higgins, 2006; Pandey, 2010).

We contribute to the existing literature on entrepreneurship and public policy by demonstrating that government size, corruption, and tax policy do not have predictably consistent effects ontwo types of entrepreneurship. To test this article's hypotheses, we use a panel of 52 countries from 2005 to 2015. The results suggest that the direction and magnitude of government size, corruption, and tax policy on different types of entrepreneurship depend on the form of entrepreneurship.

Second, we contribute to the literature on entrepreneurship and institutions by demonstrating that engagement in opportunity and necessity entrepreneurship is shaped by both the regulatory environment (tax), informal institutions (corruption), and government size. The study results suggest not all regulatory and institutional settings have a similar effect on entrepreneurship.

The remainder of the paper is structured as follows. In Section 2, we present the relevant literature and 
develop our hypotheses on the direct and moderating effects of government size, tax policy, and corruption on entrepreneurship. In Section 3, we discuss our data, method, and identification strategy. We report results in Section 4, followed by discussing implications and next steps for scholars, entrepreneurs, and policymakers in Section 5.

\section{Theoretical background and hypotheses}

\subsection{Government size and opportunity} and necessity entrepreneurship

Government size can determine how, where, and what resources are allocated in an economy, and this resource allocation can influence entrepreneurship (Williamson, 2000), shaping protections (or lack of) for entrepreneurs (Aidis et al., 2012). Large government size could mean improved ability to provide services by the government and better inputs for entrepreneurs, such as skilled workers coming out of effective education systems (Audretsch et al., 2015) and social services/benefits that the government generally provides, like health and public schools, can boost human capital and quality of life (Berry \& Lowery, 1987). Existing research suggests that human capital is associated with improved cognitive skills related to opportunity recognition and exploitation (Lofstrom, 2013).

Opportunity entrepreneurship requires access to established infrastructure such as the Internet, roads, and access to electricity (Audretsch et al., 2015), and government with resources can better develop these infrastructures than their counterpart. Well-developed infrastructures allow entrepreneurs access to information, mobility, and connectivity. A large government is also better able to invest in systems like land and property rights, and intellectual property protections that can be costly to set up by the individual entrepreneurs and divert necessary resources from the venture activity, yet these types of protections help opportunity entrepreneurs (Desai et al., 2013; Estrin et al., 2013).

Large governments can also offer social security and welfare programs that can mitigate risk and lower the opportunity cost of going into business instead of wage employment. Such programs could generate more security and encourage risk-taking. For example, if private health insurance is expensive, wage employment could be more attractive (see Fairlie et al., 2011; Holtz-Eakin et al., 1996). Health insurance costs can be a constraint on entrepreneurs, depending on the health insurance system's reach and scope (Fossen \& König, 2017). An expanded safety net could reduce the pressure for a person to generate income, encouraging risk-taking (Henrekson, 2005), particularly for welfare programs associated with monetary transfers (Heinemann, 2008). Therefore, we hypothesize that:

Hypothesis 1a(H1a): Larger government size has a positive effect on opportunity entrepreneurship.

Potential problems that could accompany larger government are discussed further, when we hypothesize on corruption. Here, we consider that if larger government means effective and efficient services and programs, it could also mean better quality of inputs, resources, and conditions for entrepreneurship. Government size can increase entrepreneurial activity by pushing individuals to undertake entrepreneurship. Manydeveloped countries have unemployment insurance (UI) and active labor market programs (ALMP) to promote entrepreneurship by pushing unemployed individuals to undertake entrepreneurship (Agwu et al., 2017; Fadahunsi \& Rosa, 2002; Laffineur et al., 2017). Unemployed individuals may be forced to undertake entrepreneurship since they do not have any other option. While the safety net provisions may serve the unemployed person's need for the short term, these programs will not support them for an extended period. The need for income generation over the longer term will push individuals to undertake necessity entrepreneurship.

Hypothesis $1 \mathrm{~b}(\mathrm{H} 1 \mathrm{~b})$ : Larger government size has a positive effect on necessity entrepreneurship.

\subsection{Corruption and opportunity} and necessity entrepreneurship

Corruption in the public sector is a de facto reality in many countries (Estrin et al., 2013; Rose-Ackerman, 1999, 2007). Corruption is commonly conceptualized as the use of public office for personal benefit (Mauro, 1995; Rose-Ackerman, 2007, 1999). Onone hand, corruption could have a "greasing" effect for entrepreneurs by providing a way to circumvent cumbersome regulations by paying bribes (Méon \& Weill, 2010); on the 
other hand, it could have a "sanding" effect for those who cannot pay (Shleifer \& Vishny, 2002) because new ventures may have limited resources (Choi \& Thum, 2005; Tonoyan et al., 2010).

Opportunity entrepreneurs need financial resources for opportunity exploitation, and corruption can increase constraints on critically important resources (see Dreher $\&$ Gassebner, 2013). Besides, corruption imposes several types of costs onopportunity entrepreneurs beyond just the obvious financial cost. It can increase the business financial costs by charging additional unseen fees on top of what is already anticipated, and redirect funds away from productivity-enhancing investments by cutting into the total volume of funding available for the business. Corruption also creates costs in terms of nonfinancial resources, shifting the entrepreneur's time to negotiating bribes and managing relationships with bureaucrats instead of engaging in value creation activity (see Tonoyan et al., 2010).

Opportunity entrepreneurs are likely to formally enter the marketplace through registration and obtaining required licenses to gain legitimacy. This legitimization process can help the opportunity entrepreneurs to get financial resources. However, corrupt government officials may use this as an exploitation opportunity by refusing to issue a permit or process a transaction without receiving a bribe (see Dreher \& Gassebner, 2013). Even after obtaining the required permissions and licenses, opportunity entrepreneurs can be vulnerable to continued exploitation by corrupt public agents (see Dreher \& Gassebner, 2013). Entrepreneurs may faceconsequences if they seek recourse and try to access protections offered by law. Bureaucrats can repeatedly exploit entrepreneurs, and each act of corruption further raises their vulnerability in a system where government agents make the laws and enforce them.

Another cost of corruption is indirect, resulting from diverted or lost public spending. These funds could be spent on education and training programs that improve the labor market, infrastructures like roads and ports, health services, and security. The diversion of funds may not have an immediate tangible effect on an entrepreneur, but this shapes and raises costs in the broader economic context in which the entrepreneur must operate. For example, corruption has been found to reduce government spending on education (Mauro, 1998); this underinvestment in training the labor market can raise costs for entrepreneurs who internalize the costs of training or acquiring skilled labor, i.e., higher salaries because of fewer local hires or costs to recruit from abroad.

Hypothesis 2a (H2a): Corruption has a negative effect on opportunity entrepreneurship.

A corrupt government agent and an entrepreneur both participate in the corrupt transaction, and government agents have the upper hand because entrepreneurs rely on them to obtain licenses and permits (Pfeffer \& Salancik, 1978). The relationship may be coercive if the entrepreneur has no other option but to engage with the bribe-seeking government agent. For necessity entrepreneurs, who might not be able to afford the registration and licensing fees or may not be willing to register, theymay react to the corrupt environment by staying in the informal sector.

Corruption can raise uncertainty over time because the entrepreneur is unsure how many future transactions will require bribes or the number of future bribes. This uncertainty fundamentally affects how an individual entrepreneur can reliably plan for costs and calculate expected profits. Engagement in the entrepreneurial activity itself has significant uncertainty, and necessity entrepreneursmight avoid engaging with corrupt officials by remaining in the informal sector and by reducing the cost of formal payments and regulation. In the long run, it increases costs, vulnerability, and is a barrier to business growth. Also, it creates uncertainty and increases the opportunity costs of staying in necessity entrepreneurship. Thereby, we hypothesize that:

Hypothesis $2 \mathrm{~b}(\mathrm{H} 2 \mathrm{~b})$ : Corruption has a negative effect on necessity entrepreneurship.

2.3 Tax and opportunity and necessity entrepreneurship

A large body of literature has found mixed results related to the relationship between the tax rate and entrepreneurship. An overly simplified interpretation could be that paying taxes discourages entrepreneurs who seek to maximize profits. However, the relationship appears to be far more nuanced and complex because tax policy affects entrepreneurs beyond simply their profit margins.

Tax policy can affect entrepreneurs through three channels: income shifting, risk subsidy, and risk- 
sharing (Cullen \& Gordon, 2007). First, income shifting occurs when tax policy redistributes income from highincome individuals to low-income individuals. This income transfer could provide more capital to entrepreneurs with less access to financial resources or in lowincome households to start a business. At the same time, this could relieve some of the pressures that push underresourced people to become necessity entrepreneurs, and mean that fewer people need to do so.

Tax policy could induce a risk subsidy effect by providing welfare services that might encourage potential entrepreneurs to take on more significant risks and forego immediate income because welfare programs could meet basic needs. Henrekson et al. (2010) argued that taxes could generate an insurance effect by offsetting total losses by serving as an insurance policy for the entrepreneur and reducing risk.

Tax policy can have a risk-sharing effect by alleviating some of the financial burdens on entrepreneurs and providing some fallback if the business fails. Domar and Musgrave (1944)described the tax system as a way for entrepreneurs to share risk under adverse conditions. If an entrepreneur can share the risk, this could encourage entrepreneurs to take on greater risk. This could mean that very successful businesses might offset costs of failure for other businesses; in this way, higher taxes could be seen by opportunity entrepreneurs as cutting deeply into their profits if they become very successful, lowering their returns to entrepreneurship, which could discourage them. Based on this discussion, we hypothesize:

Hypothesis $3 \mathrm{a}(\mathrm{H} 3 \mathrm{a})$ : Tax rate has a negative effect on opportunity entrepreneurship.

Hypothesis $3 b(\mathrm{H} 3 b)$ : Tax rate has a negative effect on necessity entrepreneurship.

\subsection{Tax, government size and opportunity} entrepreneurship and necessity entrepreneurship

Taxes and government size are interrelated (Bergh \& Henrekson, 2011). Scholars in the "spend-and-tax" school of thought suggest that higher taxes mean more spending (Goedhuys \& Sleuwaegen, 2010; Tybout, 2000). Large government and high taxescould positively influence entrepreneurship by creating and providing the necessary services and public goods(Goedhuys \& Sleuwaegen,
2010; Tybout, 2000). For example, infrastructure is an essential component for entrepreneurs to build a successful business and this resource may be more important for opportunity entrepreneurs than necessity entrepreneurs.A high quality of transportation and communication should makes it easier for an individual to engage in opportunity entrepreneurship to grow and reach customers outside the region or the country..

The government can act as a "benevolent dictator" by helping to address market failure by providing public goods otherwise not provided by the private sector and aiming to maximize social welfare (Musgrave, 1959; Pigou, 1928). Public provision such as safety are necessary for an entrepreneur to be confident about investing in entrepreneurship activity. As these new ventures grow, tax revenue generated from successful entrepreneurs can be redistributed to support public works (Henrekson, 2005).

The government can also help with the supply side of opportunity-driven and growth-oriented entrepreneurs (Estrin et al., 2013) by creating programs that support entrepreneurial activity and redistributing tax income in a way to sponsor high-quality and society-oriented businesses (Cooper, 2003; Cumming et al., 2018; Lerner \& Kegler, 2000). Manycountries have funding programs that help generate high-growth entrepreneurial activity (Cooper, 2003; Lerner \& Kegler, 2000). Therefore, although we expected higher taxes to discourage opportunity entrepreneurs directly, if a combination of larger government and taxes effectively produces conducive conditions where opportunity entrepreneurs have greater access to resources, we hypothesize:

Hypothesis 4a (H4): Government size and tax jointly increase opportunity entrepreneurship.

For necessity entrepreneurs, a high tax rate and a large government can create a complex governance mechanism that could reduce entrepreneurs' incentives to register their businesses (Estrin et al., 2013) formally. In their study of 47 countries, Aidis et al. (2012) found that a larger government sector negatively influences entrepreneurial activity. Parker (2018) argued that a large government sector could discourage entrepreneurship by reducing its payoffs because of higher taxes and will be particularly difficult for necessity-driven entrepreneurs with the lack of resources. Entrepreneurs generally seek to maximize profit (Baumol, 1990), and taxes take away a portion of profits generated by their 
efforts. A large government size also increases administrative expenditure requiring a larger budget. To support these increased expenses, in most cases, higher taxes are needed (Acemoglu, 2005). Therefore, government size and taxation can create a virtuous circle.

Necessity entrepreneurs may also enjoy the benefit of a big government, such as well-established infrastructures, subsidizing housing, and social security, which reduces the supply of necessity-driven entrepreneurs. Based on this, we hypothesize that:

Hypothesis 4b (H4): Government size and tax jointly decrease necessity entrepreneurship.

\subsection{Corruption, government size and necessity} and opportunity entrepreneurship

Government size can be related to whether there is an environment for corrupt behavior and rent-seeking by authorities (Belitski et al., 2016; Bruton et al., 2010).If larger government means more or more complex regulations to comply with, this could create the opportunity for corruption. Alesina and Angeletos (2005, p. 1241) argued that a big government could increase corruption since self-serving government agents can use regulations to extract rents from entrepreneurs (Djankov et al., 2002; Peltzman, 1976; Tullock, 1967).

As government size grows, it can crowd out private resources' efficient allocation (see Aidis et al., 2012) and redirect investing in the business, affecting both necessity and opportunity entrepreneurs. This can be accelerated by decentralization, which can emerge due to expanding government, giving public officials more opportunity to use discretion in implementing policies (Fisman \& Gatti, 2002), especially at the local level. A key argument in favor of decentralization is that it allows for "closer" governance and responsiveness to local needs, there by increasing public officials' accountability. However, proximity to local populations, particularly in areas where political and economic power may be entrenched, could raise vulnerability toexploitation (see Fisman \& Gatti, 2002). While decentralization can create additional administration layers that require greater engagement with the government (Fan et al., 2009), creating more opportunities to seek bribes from entrepreneurs (Chowdhury et al., 2019), opportunity entrepreneurs who are likely to have more access to resources may try to gain advantages by paying the bribes.

Taxpayers in corrupt countries are likely to have lower trust that revenues will be used to provide quality public services. Trust in government can bolster tax morale and deter tax evasion (see Hammar et al., 2009; Torgler, 2003), encouraging compliance with tax requirements (see Scholz \& Lubell, 1998), while mistrust reshapes incentives forentrepreneurship (Audretsch et al., 2021) and higher corruption redistributes government expenditure for corrupt needs and rentseeking. When faced with high corruption and a low level of government trust, both potential necessity and opportunity entrepreneurs may be wary of exposure to rent-seeking.

Subsidy programs are another area where government officials can exercise discretion, and in corrupt countries, government expenditure and support may be directed in ways that providelittle benefit for the community and region. Corruption can affect the allocation of resources and social programs targeting appropriate places (Blackburn \& Forgues-Puccio, 2007), with both types of entrepreneurs losing from high corruption and larger government. Paying bribes could limit entrepreneur's growth and make them withdraw from the market, while high uncertainty and the tax burden could prevent new entry, including necessity-driven entrepreneurs. For the reasons discussed above, we thus consider that:

Hypothesis 5a(H5a): Large government and high corruption will reduce opportunity entrepreneurship. Hypothesis $5 b(\mathrm{H} 5 b)$ : Large government and high corruption will reduce necessity entrepreneurship.

\section{Data and method}

\subsection{Data}

We construct our sample by matching data from the following sources at the country level for 2005-2015: World Bank Group Entrepreneurship Snapshot (WBGES), World Development Indicators (WDI), Doing Business (DB) Database, Global Entrepreneurship Monitor (GEM) National Expert Survey and Adult Population survey, and the Worldwide Governance Indicators (WGI) and Internationally Monetary Fund. 
The WBGES provides an internationally comparable indicator of new business registrations at the country level worldwide, based on business registrar information. The WDI is a compilation of comparable national statistics on a wide range of economic trends, including poverty and development. The DB Project tracks business regulations at the national and subnational levels, using several indicators to capture different regulatory dimensions. The GEM is a cross-national comparative data effort that uses general population surveys (Adult Population Survey) to measure the nature and level of entrepreneurial activity and expert-based surveys (National Expert Survey) to track the conditions in the environment for entrepreneurship. GEM data has been used extensively in the entrepreneurship literature to understand various phenomena related to entrepreneurship. The WGI report on governance indicators at the country level, based on a combination of the businesses, citizens, and expert survey respondents' views.

Our sample captures variance across both developed and developing countries for 2005-2015, and our final dataset covers 52 countries and comprises 272 observations. We use unbalanced panel data with missing values for several countries (see Appendix, Table 4 for details).

It is essential to acknowledge the heterogeneity that characterizes both the explanatory and dependent variables in our study, which we argue is a core to gaining a more accurate understanding of the nuances embedded in the relationships being tested (see Audretsch et al., 2019b).

\subsection{Dependent variables}

We use two measures for entrepreneurship. These measures are taken from GEM's Adult Population Survey: necessity entrepreneurship and opportunity entrepreneurship, which are calculated as a subset of total entrepreneurial activity (TEA), defined as the percentage of the population that is either a nascent entrepreneur actively involved in starting a new venture or an ownermanager of a new business less than 42 months old. Necessity entrepreneurship is measured as the percentage of total entrepreneurial activity that reported no other option for work. Opportunity entrepreneurship is measured as the percentage of total entrepreneurial activity driven by opportunity, reporting that the main driver for being involved in entrepreneurship is to be independent or increase (rather than maintain) income
(Reynolds et al., 2005). This distinction has allowed scholars to observe the impact of economic and sociocultural factors on entrepreneurial motivation (Hechavarria \& Reynolds, 2009).

\subsection{Explanatory variables}

We include various types of government expenditures (as a percentage of GDP) from the IMF Government Finance Statistics (GFS, 2021) to measure the link between government size and entrepreneurship types. Based on Estrin et al. (2013) and Aidis et al. (2012), we use a range of public expenditure measures, such as expenditure on public order and safety to GDP, expenditure on economic affairs to GDP, expenditure on housing and community amenities to GDP, expenditure on recreation, culture, and religion to GDP, education expenditure to GDP, and social security expenditure to GDP. We also include a measure of public administration expenditure in total government expenditure, which is predicted to negatively affect entrepreneurship (Bruton et al., 2010).

Corruption is taken from the WGI, reflecting the extent to which public power is exercised for private gain, including petty and grand forms of corruption and the capture of the state elites and private interests (Anokhin \& Schulze, 2009). Country scores range from - 2.5 (high corruption) to 2.5 (low corruption). We reversed the measure by multiplying by -1 so that 2.5 corresponds to high corruption, and -2.5 corresponds to low corruption.

Our measure for the tax rate is the percentage of taxes and mandatory contributions payable by businesses after deductions and exemptions in commercial profits (Djankov et al., 2010; Kaufmann et al., 2009; World Bank, 2004, 2007). Recent research suggests that the complexity of paying taxes, in addition to the tax rate, matters (Braunerhjelm et al., 2021; Djankov et al., 2010), so we also include tax time from the DB database, measured as the number of days needed to prepare and pay taxes (Belitski et al., 2016).

\subsection{Control variables}

Several control variables reflect vital trends that could affect entrepreneurship in our study. Economic development is an essential consideration for entrepreneurship (Parker, 2004) and is measured as GDP per capita (constant 2010 USD), taken from WDI. We use GDP 
per capita to construct a binary variable "rich" that takes the value of one if a country's GDP per capita is greater or equal to 25,000 USD (constant 2010 USD), zero otherwise. GDP per capita is highly correlated with corruption, while "rich" is not and could be included in the model. Human capital can take different forms and is a typical theoretical lens to study entrepreneurship (see Marvel et al., 2016); our measure for human capital is the percentage of the population enrolled in tertiary education, taken from WDI.

We account for information about private credit bureau, taken from $\mathrm{DB}$, and measured as a private credit registry that gathers information about individuals and firms listed by a private credit bureau with information on their borrowing history from the past 5 years (a percentage of the population). The availability of credit is measured by domestic credit given to the private sector by the banks (\% of GDP) was taken from WDI (Chowdhury et al., 2019).

We account for unemployment in a country because it can motivate some individuals to seek entrepreneurial activity (Wennekers et al., 2005) and can be useful to understand necessity and opportunity entrepreneurship outcomes. Unemployment was measured as the percentage of the labor force available for and seeking employment, but without employment, taken from WDI. We also account for labor force participation by including labor force participation, gathered from WDI, reflecting the percentage of the total population participating in the labor force.

We control for entrepreneurs' perceptions of the environment in which they are embedded (Edelman \& YliRenko, 2010). Therefore, we include government support for entrepreneurship, measured as the extent to which public policies support entrepreneurship collected from GEM. This variable is expected to have a positive effect on entrepreneurship activity.

Definitions and data sources for all variables in our study are provided in Table 1.

\section{Empirical strategy}

We first check correlations among our variables: Necessity and opportunity entrepreneurship are negatively correlated $(-0.75)$. Government safety expenditure, expenditure on housing, and economic affairs are positively associated with necessity entrepreneurship, while they are negatively associated with opportunity entrepreneurship (see Table 2).

Corruption is positively correlated with necessity entrepreneurship (0.68) and negatively with opportunity entrepreneurship $(-0.60)$.

Our first concern was the covariance structure of the control variable matrix. We are unlikely to estimate partial effects without bias, as several variables included in the model are causally related; this is not a multicollinearity issue but an endogeneity issue. First, government size can be a function of the tax base's size and government programs, including those serving businesses and the unemployed.

Second, corruption can be associated with entry regulation, taxes, licensing, and many other regulations (Belitski et al., 2016; Méon \& Sekkat, 2005; RoseAckerman, 2007). Third, government expenditure could create more opportunities for corruption, such as through public procurement. Unobserved factors that affect government size could also affect corruption and taxes.

Because these variables are causally related to each other, the effects of interrelated variables are being mediated (moderated) by others, and they cannot be included together in the same regressions (Angrist \& Pischke, 2008), this makes it difficult to assess the independent effect of any one of the variables. We control for this interdependency effect using an alternative modeling strategy by fitting four models jointly.

First, we combine four equations in a mixed-process model, incorporating both continuous responses (entrepreneurship type, government size) and ordinal responses (corruption). We modeled a simultaneous system of equations: first for necessity entrepreneurship, second for opportunity entrepreneurship, third for government size, and fourth for corruption. Second, the cmp framework in Stata 15 allows for the different observations to enter each equation in the model, with available observations being used to estimate each equation parameter.

Given the potential interdependence between the four equations, they should be estimated simultaneously. The FIML estimates produced by cmp estimation can handle this form of simultaneity (Baum et al., 2017). A maximum likelihood estimator of a seemingly unrelated equation (SUR) system (Zellner, 1962) can consistently estimate parameters in an essential subclass of mixedprocess simultaneous systems: those are recursive and simultaneous (Roodman 2011). Government size is 
Table 1 Variable descriptions, sources, and descriptive statistics

\begin{tabular}{|c|c|c|c|c|c|c|}
\hline Variable & Description & Source & Mean & $\begin{array}{l}\text { Std. } \\
\text { dev. }\end{array}$ & Min & Max \\
\hline Necessity entrepreneurship & $\begin{array}{l}\text { Percentage of those involved in Total early-stage Entrepreneurial Ac- } \\
\text { tivity (TEA) who claim they had no other options for work and just } \\
\text { to maintain their income. TEA-the percentage of 18-64 population } \\
\text { who are either a nascent entrepreneur or owner-manager of a new } \\
\text { business. }\end{array}$ & GEM & 22.44 & 12.31 & 4.00 & 61.00 \\
\hline $\begin{array}{l}\text { Opportunity } \\
\text { entrepreneurship }\end{array}$ & $\begin{array}{l}\text { Percentage of those involved in TEA who claim to be driven by } \\
\text { opportunity, and who indicate the main driver for being involved is } \\
\text { being independent or increasing their income }\end{array}$ & GEM & 51.10 & 13.19 & 10.00 & 82.00 \\
\hline Rich & $\begin{array}{l}\text { Binary variable }=1 \text { for countries with GDP per capita in } 2010 \text { USD } \\
\text { constant prices greater or equal } 25,000 \mathrm{USD} \text {, zero otherwise }\end{array}$ & WDI & 0.47 & 0.50 & 0.00 & 1.00 \\
\hline Private credit bureau & $\begin{array}{l}\text { Private credit registry coverage: individuals and firms listed by a } \\
\text { private credit bureau with information on their borrowing history } \\
\text { from the past } 5 \text { years (\% of population) }\end{array}$ & DB & 12.66 & 21.22 & 0.00 & 100.00 \\
\hline Human capital & $\begin{array}{l}\text { Total enrollment in tertiary education (ISCED } 5 \text { and } 6 \text { ), regardless of } \\
\text { age, } 5 \text {-year age group following on from secondary school leaving } \\
\text { (\% of total population) }\end{array}$ & WDI & 55.70 & 19.77 & 4.00 & 97.97 \\
\hline Tax rate & $\begin{array}{l}\text { The amount of taxes and mandatory contributions payable by } \\
\text { businesses after accounting for allowable deductions and } \\
\text { exemptions as a share of commercial profits. }\end{array}$ & DB & 43.94 & 17.91 & 8.30 & 107.70 \\
\hline Corruption & $\begin{array}{l}\text { Perceptions of the extent to which public power is exercised for private } \\
\text { gain, including both petty and grand forms of corruption, as well as } \\
\text { "capture" of the state by elites and private interests. The score ranges } \\
\text { from }-2.5 \text { to } 2.5 \text {. We reversed the order by multiplying by }-1 \text { ( } 2.5 \\
=\text { most corrupt, }-2.5 \text { = least corrupt). }\end{array}$ & WGI & -0.67 & 1.01 & $\begin{array}{l}- \\
2 .- \\
55\end{array}$ & 1.09 \\
\hline Tax time & Time required to prepare and pay taxes (hours) & DB & 289.50 & 333.40 & 12.00 & 2600.00 \\
\hline Credit & $\begin{array}{l}\text { Domestic credit to private sector by banks (\% GDP) refers to financial } \\
\text { resources provided to the private sector by other depository } \\
\text { corporations (deposit taking corporations except central banks). }\end{array}$ & WDI & 82.40 & 53.33 & 10.10 & 312.15 \\
\hline Entry density & $\begin{array}{l}\text { New business density (new firm registrations per } 1000 \text { people ages } \\
15-64 \text { ) }\end{array}$ & WBGES & 4.06 & 4.46 & 0.04 & 28.12 \\
\hline Unemployment & $\begin{array}{l}\text { Unemployment refers to the share of the labor force that is without } \\
\text { work but available for and seeking employment ( } \% \text { of total labor } \\
\text { force). }\end{array}$ & WDI & 7.89 & 5.20 & 0.70 & 32.20 \\
\hline Government support & $\begin{array}{l}\text { The extent to which public policies support entrepreneurship. (a) } \\
\text { Entrepreneurship as a relevant economic issue and (b) taxes or } \\
\text { regulations are either size-neutral or encourage new and SMEs } \\
\text { (scale 1-5) }\end{array}$ & GEM & 2.55 & 0.45 & 1.65 & 4.55 \\
\hline Labor force & $\begin{array}{l}\text { Labor force participation rate, } \% \text { of total population (modeled ILO } \\
\text { estimate) }\end{array}$ & WDI & 61.04 & 7.60 & 42.36 & 82.24 \\
\hline \multicolumn{7}{|c|}{ Government expenditure indicators } \\
\hline Public services expenditure & Expenditure on general public services, \% GDP & IMF & 6.38 & 2.09 & 3.23 & 17.11 \\
\hline Safety expenditure & Expenditure on public order and safety, \% GDP & IMF & 1.72 & 0.46 & 0.82 & 3.70 \\
\hline Economic affair expenditure & Expenditure on economic affairs, \% GDP & IMF & 5.14 & 2.34 & 1.78 & 25.04 \\
\hline Housing expenditure & Expenditure on housing and community amenities, \% GDP & IMF & 0.88 & 0.68 & -0.13 & 3.57 \\
\hline Culture expenditure & Expenditure on recreation, culture, and religion, \% GDP & IMF & 1.30 & 0.55 & 0.34 & 3.57 \\
\hline Education expenditure & Expenditure on education, \% GDP & IMF & 5.19 & 1.12 & 3.21 & 8.09 \\
\hline Social security expenditure & Expenditure on social protection, \% GDP & IMF & 15.70 & 4.34 & 4.58 & 24.84 \\
\hline Public administration share & $\begin{array}{l}\text { Share of public administration expenditure in total government } \\
\text { expenditure }\end{array}$ & IMF & 14.09 & 3.50 & 7.96 & 24.65 \\
\hline
\end{tabular}

Source: calculation based on GEM, Global Entrepreneurship Monitor; WEF, World Economic Forum Global Competitiveness Report (2005-2016); DB, Doing Business; WDI, World Development Indicators; EFI, Economic Freedom Index; WGI, World Governance Indicator; $I M F$, International Monetary Fund 
Table 2 Correlation matrix

\begin{tabular}{|c|c|c|c|c|c|c|c|c|c|c|c|c|c|c|c|c|c|c|c|}
\hline 1. Necessity & 1 & 2 & 3 & 4 & 5 & 6 & 7 & 8 & 9 & 10 & 11 & 12 & 13 & 14 & 15 & 16 & 17 & 18 & 19 \\
\hline 2. Opportunity & $-0.75 *$ & 1 & & & & & & & & & & & & & & & & & \\
\hline 3. Rich & $-0.65 *$ & $0.58^{*}$ & 1 & & & & & & & & & & & & & & & & \\
\hline 4. Private Credit Bureau & -0.01 & $-0.13^{*}$ & -0.01 & 1 & & & & & & & & & & & & & & & \\
\hline 5. Human Capital & $-0.46 *$ & $0.44^{*}$ & $0.63^{*}$ & -0.04 & 1 & & & & & & & & & & & & & & \\
\hline 6. Tax rate & 0.03 & -0.01 & $-0.12^{*}$ & $0.20^{*}$ & 0.03 & 1 & & & & & & & & & & & & & \\
\hline 7. Corruption & $0.68^{*}$ & $-0.60^{*}$ & $-0.66^{*}$ & 0.08 & $-0.52^{*}$ & $0.24^{*}$ & 1 & & & & & & & & & & & & \\
\hline 8. Tax time & $0.26^{*}$ & $-0.14^{*}$ & $-0.35^{*}$ & 0.10 & $-0.21 *$ & $0.34^{*}$ & $0.44^{*}$ & 1 & & & & & & & & & & & \\
\hline 9. Credit & $-0.56^{*}$ & $0.43^{*}$ & $0.66 *$ & -0.03 & $0.44 *$ & $-0.37^{*}$ & $-0.62^{*}$ & $-0.38 *$ & 1 & & & & & & & & & & \\
\hline 10. Entry density & $-0.30 *$ & $0.22^{*}$ & $0.15^{*}$ & $-0.13^{*}$ & $0.19^{*}$ & $-0.26 *$ & $-0.33^{*}$ & $-0.18^{*}$ & $0.45^{*}$ & 1 & & & & & & & & & \\
\hline 11. Unemployment & $0.56^{*}$ & $-0.61 *$ & $-0.38 *$ & $0.177^{*}$ & $-0.38^{*}$ & $-0.14^{*}$ & $0.35^{*}$ & 0.01 & $-0.27^{*}$ & -0.06 & 1 & & & & & & & & \\
\hline 12. Government support & $-0.32^{*}$ & $0.29^{*}$ & $0.36^{*}$ & -0.03 & 0.05 & $-0.22^{*}$ & $-0.46 *$ & $-0.35 *$ & $0.43^{*}$ & 0.04 & $-0.16^{*}$ & 1 & & & & & & & \\
\hline 13. Labor Force & $-0.54 *$ & $0.48^{*}$ & $0.42^{*}$ & $-0.21 *$ & $0.20^{*}$ & $-0.15^{*}$ & $-0.63^{*}$ & $-0.22^{*}$ & $0.56^{*}$ & $0.33^{*}$ & $-0.46^{*}$ & $0.29 *$ & 1 & & & & & & \\
\hline 14. Safety expenditure & $0.45^{*}$ & $-0.53^{*}$ & $-0.52^{*}$ & 0.12 & $-0.51^{*}$ & -0.03 & $0.57^{*}$ & $0.25 *$ & $-0.27 *$ & 0.06 & $0.61^{*}$ & $-0.34 *$ & $-0.45 *$ & 1 & & & & & \\
\hline 15. Economic affairs expenditure & $0.23^{*}$ & $-0.26^{*}$ & $-0.21^{*}$ & 0.04 & -0.08 & -0.11 & 0.13 & -0.01 & -0.09 & 0.04 & $0.19 *$ & -0.11 & $-0.21^{*}$ & $0.24^{*}$ & 1 & & & & \\
\hline 16. Housing expenditure & $0.57^{*}$ & $-0.42^{*}$ & $-0.61^{*}$ & -0.07 & $-0.40 *$ & $-0.26 *$ & $0.49 *$ & $0.15^{*}$ & $-0.22 *$ & -0.01 & $0.39 *$ & $-0.18^{*}$ & $-0.38 *$ & $0.53^{*}$ & $0.34^{*}$ & 1 & & & \\
\hline 17. Culture expenditure & $-0.18^{*}$ & $0.23^{*}$ & 0.01 & -0.02 & 0.11 & $-0.29 *$ & $-0.21^{*}$ & -0.05 & $0.32^{*}$ & $0.39 *$ & -0.13 & 0.02 & $0.32^{*}$ & -0.11 & $0.27 *$ & 0.08 & 1 & & \\
\hline 18. Education expenditure & $-0.51^{*}$ & $0.44^{*}$ & $0.39 *$ & 0.04 & $0.33^{*}$ & -0.12 & $-0.55 *$ & $-0.22 *$ & $0.42^{*}$ & $0.52^{*}$ & $-0.20^{*}$ & $0.23^{*}$ & $0.43^{*}$ & $-0.19 *$ & -0.07 & $-0.42^{*}$ & $0.50 *$ & 1 & \\
\hline 19. Social security expenditure & $-0.22^{*}$ & 0.12 & $0.28^{*}$ & 0.11 & $0.26^{*}$ & $0.33^{*}$ & $-0.30 *$ & $-0.19 *$ & 0.03 & $-0.36 *$ & -0.04 & $0.27^{*}$ & -0.03 & $-0.31^{*}$ & -0.06 & $-0.24 *$ & -0.02 & 0.11 & 1 \\
\hline 20. Public administration share & -0.01 & -0.06 & -0.12 & 0.09 & 0.12 & $0.32^{*}$ & $0.26^{*}$ & $0.22^{*}$ & $-0.20 *$ & $-0.32 *$ & 0.06 & -0.11 & $-0.28^{*}$ & $-0.16^{*}$ & $-0.21^{*}$ & $-0.22 *$ & -0.11 & -0.07 & 0.06 \\
\hline
\end{tabular}

Note: Level of statistical significance $* 0.05 \%$. Source: calculation based on GEM, Global Entrepreneurship Monitor; WEF, World Economic Forum Global Competitiveness Report (2005-2016); DB, Doing Business; WDI, World Development Indicators; EFI, Economic Freedom Index; WGI, World Governance Indicator; $I M F$, International Monetary Fund

likely to influence corruption and vice versa and is associated with several explanatory factors hypothesized to influence government size, corruption, and entrepreneurship. There is potentially a more efficient approach as it allows estimation of possible crossequation correlations for each country between equations with entrepreneurship types as dependent variables and equations with the institutional environment as dependent variables. Besides, we controlled for the year and country-specific effects.

Given the panel structure of the data, the equation was estimated using the observations from the various datasets that could be matched by country and year. The entire sample includes 272 observations for 52 countries. We used the fixed-effects (FE) estimator as it concentrates on differences that, over time, characterize a country. This is why the FE estimator is also referred to as the "within" estimator. It explains to what extent a given country's change in a variable of interest affects its entrepreneurship rates. Our estimates are "within" effect, allowing us to identify the factors that explain the differences between the countries in the panel and control for country-specific unobserved characteristics over time. Thus, the FE estimates should provide a more exhaustive scenario of the drivers of entrepreneurship than random effect estimation, which follows a stronger assumption. The use of the FE estimator also resolves a simultaneity bias induced by unobservable factors and is preferred.

The model with country and time-fixed effects is as follows:

$E_{i, t}=\beta_{0}+\sum_{i=1}^{n} \beta_{11} x_{i, t-1}+\sum_{j=1}^{n} \beta_{12} z_{i, t-1}+\rho_{1 i}+\lambda_{1 t}+u_{1(i, t-1)}$

where $E_{i, t}$ is a necessity (opportunity) entrepreneurship in a country $i$ at time $t$. We deal with panel data for each dependent and independent variable. $X_{i, t-1}$ is a vector of explanatory variables - the size of government (variety of government expenditures), corruption, and tax rate of country $i$ at time $t . Z_{i, t-1}$ is a vector of control exogenous variables for a country $i$ at time $t$. Moreover, we include two additional vectors of fixed country effects: $\rho_{i}$, controlling for unobserved heterogeneity of a country $i$ over time $t$, and $\lambda_{t}$ is a vector of time-fixed (entity invariant) effects over each period $t$ across all 
countries $i$. The error term is denoted by $u_{i, t-1}$ for a country $i$, at time $t$.

We lagged all explanatory and control variables by 1 year for robustness checks and to rule out possible endogeneity in all equations. There could be a time lag for tax policy, government spending, and corruption to affect and shape entrepreneurs' behavior. For example, a new tax rate could be passed in 1 year but enforced in the following year, or it could take several months for entrepreneurs to learn about new government programs. It is plausible to assume that regulatory changes and government expenditure will affect outcomes in the next financial year, as they cannot be immediately applied.

\section{Results}

The results of our fixed-effects panel data estimations are reported in Table 3. Results are grouped as follows: specifications 1-4 are for necessity entrepreneurship, and specifications 5-8 are for opportunity entrepreneurship.

In hypotheses $1 \mathrm{a}$ and $1 \mathrm{~b}$, we posited that government size and both types of entrepreneurship have a positive relationship. Our results do not support H1a that government size increases opportunity entrepreneurship; an increase ineconomic affairs expenditure by $1 \%$ to GDP reduces opportunity entrepreneurship by $(\beta=-0.77, p<0.05)$. An increase in culture and recreation expenditure by the government reduces opportunity entrepreneurship by $8.79 \%(\beta=-8.79, p<0.01)$, while an increase in social security expenditure reduces opportunity entrepreneurship by $2.20 \%(\beta=-2.20, p$ $<0.01$ ). Interestingly, an increase of public administration share in total government expenditure reduces opportunity entrepreneurship by $1.51 \%$ ( $\beta=$ $-1.51, p<0.001$ ), which could be associated with a negative effect of bureaucratic government (Aidis et al., 2012; Estrin et al., 2013). With regard to hypothesis $1 \mathrm{~b}$, while we find that social security expenditure is positively associated with necessity entrepreneurship ( $\beta=1.55, p<0.05)$, supporting $\mathrm{H} 1 \mathrm{~b}$, we find that safety-related expenditure reduces necessity entrepreneurship $(\beta=-12.50$, $p<0.01)$.

We find strong support for $\mathrm{H} 2 \mathrm{a}$ and $\mathrm{H} 2 \mathrm{~b}-$ corruption has a negative effect on both necessity $(\beta=-5.87, p<0.05)$ (spec. 2, Table 3) and opportunity $(\beta=-10.49, p<0.05)$ (spec. 6, Table 3). Given the confidence intervals' distribution, corruption's negative effect on opportunity entrepreneurship is twice as strong as on necessity entrepreneurship, demonstrating that opportunity entrepreneurship is worse affected by corruption.

In $\mathrm{H} 3 \mathrm{a}$ and $\mathrm{H} 3 \mathrm{~b}$, we posited that the tax rate has a negative impact on both necessity and opportunity entrepreneurship. We find support for both H3a and $\mathrm{H} 3 \mathrm{~b}$ : an increase of $1 \%$ in tax will reduce necessity entrepreneurship by $0.43 \%(\beta=-0.43, p<0.01)$ (spec. 2, Table 3$)$ and opportunity by $0.45 \%(\beta=$ $-0.45, p<0.01$ ) (spec. 6 , Table 3 ). The effect of the tax change on both types of entrepreneurs is very similar (see Braunerhjelm et al., 2021).

In $\mathrm{H} 4 \mathrm{a}$ and $\mathrm{H} 4 \mathrm{~b}$, we posited that an increase in government size and tax rate increases opportunity entrepreneurship and reduces necessity entrepreneurship, respectively. When we consider opportunity entrepreneurship (spec 7, Table 3), we note that only an increase in tax rate and public administration expenditure share adds to opportunity entrepreneurship $(\beta=0.11, p<0.01)$, while the effect of public administration expenditure share remains negative and statistically significant, partly supporting H4a. Other interaction coefficients in spec. 7 (Table 3) are insignificant, which means that an increase in tax rate and government size does not change opportunity entrepreneurship. We found a negative effect of housing government expenditure on necessity entrepreneurship $(\beta=-0.44, p<0.01)$ (spec. 3, Table 3) supporting H4b. Other interactions remain insignificant (spec.3, Table 3).

Finally, we found that an increase in social security expenditure in countries with high corruption increases necessity $(\beta=1.34, p<0.05)$ (spec. 4 , Table 3 ) entrepreneurship and reduces opportunity entrepreneurship $(\beta=-1.04, p<0.05)$ (spec. 8, Table 3). An increase in government size related to economic affairs expenditure facilitates necessity entrepreneurship by $1.31 \%$, which contrasts our 
Table 3 Fixed-effects estimation results

\begin{tabular}{|c|c|c|c|c|c|c|c|c|}
\hline Specification & (1) & (2) & (3) & (4) & $(5)$ & (6) & (7) & (8) \\
\hline DV & \multicolumn{4}{|c|}{ Necessity entrepreneurship } & \multicolumn{4}{|c|}{ Opportunity entrepreneurship } \\
\hline \multirow[t]{2}{*}{ Stepwise analysis } & Basic & $\begin{array}{l}\text { Government } \\
\text { expenditure }\end{array}$ & \multicolumn{2}{|c|}{$\begin{array}{l}\text { Interaction of govt. } \\
\text { expenditure and }\end{array}$} & Basic & $\begin{array}{l}\text { Government } \\
\text { expenditure }\end{array}$ & \multicolumn{2}{|c|}{$\begin{array}{l}\text { Interaction of govt. } \\
\text { expenditure and }\end{array}$} \\
\hline & & & $\begin{array}{r}\text { Profit } \\
\text { tax }\end{array}$ & Corruption & & & Profit tax & Corruption \\
\hline Rich & $\begin{array}{l}1.20 \\
(7.22)\end{array}$ & $\begin{array}{l}1.56 \\
(6.84)\end{array}$ & $\begin{array}{l}1.21 \\
(6.81)\end{array}$ & $\begin{array}{l}0.89 \\
(6.71)\end{array}$ & $\begin{array}{l}-2.35 \\
(8.75)\end{array}$ & $\begin{array}{l}-0.71 \\
(7.88)\end{array}$ & $\begin{array}{l}-1.87 \\
(7.72)\end{array}$ & $\begin{array}{l}-0.60 \\
(7.78)\end{array}$ \\
\hline Private credit bureau & $\begin{array}{l}-0.02 \\
(0.09)\end{array}$ & $\begin{array}{l}-0.41 * * * \\
(0.14)\end{array}$ & $\begin{array}{c}- \\
0.54- \\
* * * \\
(0.16)\end{array}$ & $\begin{array}{l}-0.40^{* * * *} \\
(0.14)\end{array}$ & $\begin{array}{l}0.30 * * * \\
(0.08)\end{array}$ & $\begin{array}{l}0.53 * * * \\
(0.11)\end{array}$ & $\begin{array}{l}0.48 * * * \\
(0.12)\end{array}$ & $\begin{array}{l}0.52 * * * \\
(0.11)\end{array}$ \\
\hline Human capital & $\begin{array}{l}-0.14 \\
(0.28)\end{array}$ & $\begin{array}{l}0.23 \\
(0.33)\end{array}$ & $\begin{array}{l}0.22 \\
(0.35)\end{array}$ & $\begin{array}{l}0.18 \\
(0.32)\end{array}$ & $\begin{array}{l}0.37^{*} \\
(0.24)\end{array}$ & $\begin{array}{l}0.89 * * \\
(0.38)\end{array}$ & $\begin{array}{l}0.69^{*} \\
(0.39)\end{array}$ & $\begin{array}{l}0.92 * * \\
(0.37)\end{array}$ \\
\hline Tax rate $(\mathrm{H} 3)$ & $\begin{array}{l}-0.19 \\
(0.13)\end{array}$ & $\begin{array}{l}-0.43^{* *} \\
(0.20)\end{array}$ & $\begin{array}{c}- \\
0.48- \\
* * \\
(0.21)\end{array}$ & $\begin{array}{l}-0.25^{* *} \\
(0.11)\end{array}$ & $\begin{array}{l}0.10 \\
(0.15)\end{array}$ & $\begin{array}{l}-0.45^{* *} \\
(0.22)\end{array}$ & $\begin{array}{l}- \\
2.75^{*}- \\
* * \\
(1.02)\end{array}$ & $\begin{array}{l}0.22 \\
(0.24)\end{array}$ \\
\hline Corruption (H2) & $\begin{array}{l}-4.87 \\
(3.39)\end{array}$ & $\begin{array}{l}-5.87^{*} \\
(3.27)\end{array}$ & $\begin{array}{c}8.31- \\
* * \\
(4.16)\end{array}$ & $\begin{array}{l}-8.96^{* * *} \\
(4.53)\end{array}$ & $\begin{array}{c}- \\
10.1- \\
3^{* *} \\
(4.02)\end{array}$ & $\begin{array}{l}-10.49 * * \\
(4.37)\end{array}$ & $\begin{array}{l}-6.74 * * \\
(3.56)\end{array}$ & $\begin{array}{l}-24.59 \\
(15.98)\end{array}$ \\
\hline Tax time & $\begin{array}{l}0.01 \\
(0.01)\end{array}$ & $\begin{array}{l}0.01 \\
(0.01)\end{array}$ & $\begin{array}{l}0.01^{*} \\
(0.01)\end{array}$ & $\begin{array}{l}0.01 \\
(0.01)\end{array}$ & $\begin{array}{l}0.01 \\
(0.01)\end{array}$ & $\begin{array}{l}0.01 \\
(0.01)\end{array}$ & $\begin{array}{l}0.01 \\
(0.01)\end{array}$ & $\begin{array}{l}0.01 \\
(0.01)\end{array}$ \\
\hline Credit & $\begin{array}{l}0.01 \\
(0.03)\end{array}$ & $\begin{array}{l}0.02 \\
(0.04)\end{array}$ & $\begin{array}{l}0.03 \\
(0.04)\end{array}$ & $\begin{array}{l}-0.01 \\
(0.05)\end{array}$ & $\begin{array}{l}-0.03 \\
(0.04)\end{array}$ & $\begin{array}{l}-0.08 * * \\
(0.04)\end{array}$ & $\begin{array}{l}-0.10 * * \\
(0.04)\end{array}$ & $\begin{array}{l}-0.05 \\
(0.05)\end{array}$ \\
\hline Entry density & $\begin{array}{l}-0.67 * \\
(0.36)\end{array}$ & $\begin{array}{l}-0.27 \\
(0.49)\end{array}$ & $\begin{array}{l}-0.22 \\
(0.50)\end{array}$ & $\begin{array}{l}-0.61 \\
(0.51)\end{array}$ & $\begin{array}{l}-0.02 \\
(0.40)\end{array}$ & $\begin{array}{l}-0.24 \\
(0.52)\end{array}$ & $\begin{array}{l}-0.48 \\
(0.52)\end{array}$ & $\begin{array}{l}0.04 \\
(0.54)\end{array}$ \\
\hline Unemployment & $\begin{array}{l}0.67 * * * \\
(0.23)\end{array}$ & $\begin{array}{l}0.49 \\
(0.33)\end{array}$ & $\begin{array}{l}0.48 \\
(0.34)\end{array}$ & $\begin{array}{l}0.51 \\
(0.33)\end{array}$ & $\begin{array}{c}- \\
1.31- \\
* * * \\
(0.26)\end{array}$ & $\begin{array}{l}-1.17^{* * * *} \\
(0.34)\end{array}$ & $\begin{array}{l}- \\
{ }^{-} 1.17 *_{-} \\
* * \\
(0.35)\end{array}$ & $\begin{array}{l}-1.34 * * * \\
(0.35)\end{array}$ \\
\hline Government support & $\begin{array}{l}-1.44 \\
(2.44)\end{array}$ & $\begin{array}{l}-5.22 \\
(3.36)\end{array}$ & $\begin{array}{l}-6.33^{*} \\
(3.61)\end{array}$ & $\begin{array}{l}-7.01 * \\
(3.61)\end{array}$ & $\begin{array}{l}5.32 * \\
(2.91)\end{array}$ & $\begin{array}{l}-1.28 \\
(3.79)\end{array}$ & $\begin{array}{l}3.10 \\
(3.99)\end{array}$ & $\begin{array}{l}0.30 \\
(4.03)\end{array}$ \\
\hline Labor force & $\begin{array}{l}-0.27 \\
(0.19)\end{array}$ & $\begin{array}{l}-0.08 \\
(0.34)\end{array}$ & $\begin{array}{l}0.05 \\
(0.36)\end{array}$ & $\begin{array}{l}-0.20 \\
(0.35)\end{array}$ & $\begin{array}{l}-0.03 \\
(0.22)\end{array}$ & $\begin{array}{l}-0.38 \\
(0.37)\end{array}$ & $\begin{array}{l}-0.45 \\
(0.39)\end{array}$ & $\begin{array}{l}-0.01 \\
(0.38)\end{array}$ \\
\hline Safety expenditure (H1) & & $\begin{array}{l}-12.50 * * \\
(5.72)\end{array}$ & $\begin{array}{c}- \\
7.94- \\
* * \\
(4.06)\end{array}$ & $\begin{array}{l}-12.15^{*} \\
(6.14)\end{array}$ & & $\begin{array}{l}5.57 \\
(5.47)\end{array}$ & $\begin{array}{l}13.33 \\
(74.73)\end{array}$ & $\begin{array}{l}13.35^{* * *} \\
(6.33)\end{array}$ \\
\hline Economic affairs expenditure (H1) & & $\begin{array}{l}0.25 \\
(0.27)\end{array}$ & $\begin{array}{l}-0.20 \\
(1.22)\end{array}$ & $\begin{array}{l}2.56 * * \\
(1.14)\end{array}$ & & $\begin{array}{l}-0.77^{* *} \\
(0.31)\end{array}$ & $\begin{array}{l}-1.37 \\
(1.30)\end{array}$ & $\begin{array}{l}0.04 \\
(1.16)\end{array}$ \\
\hline Housing expenditure (H1) & & $\begin{array}{l}-1.24 \\
(1.95)\end{array}$ & $\begin{array}{l}13.07 * * \\
(6.28)\end{array}$ & $\begin{array}{l}-3.71 \\
(4.39)\end{array}$ & & $\begin{array}{l}-2.86 \\
(2.16)\end{array}$ & $\begin{array}{l}-8.93 \\
(7.03)\end{array}$ & $\begin{array}{l}-8.18^{*} \\
(4.79)\end{array}$ \\
\hline Culture expenditure (H1) & & $\begin{array}{l}3.63 \\
(4.32)\end{array}$ & $\begin{array}{l}-7.21 \\
(13.03)\end{array}$ & $\begin{array}{l}4.97 \\
(7.32)\end{array}$ & & $\begin{array}{l}-8.79 * \\
(4.84)\end{array}$ & $\begin{array}{l}-3.72 \\
(14.58)\end{array}$ & $\begin{array}{l}-14.80 * \\
(7.86)\end{array}$ \\
\hline Education expenditure (H1) & & $\begin{array}{l}0.61 \\
(2.08)\end{array}$ & $\begin{array}{l}5.75 \\
(6.99)\end{array}$ & $\begin{array}{l}-0.18 \\
(3.16)\end{array}$ & & $\begin{array}{l}-0.85 \\
(2.12)\end{array}$ & $\begin{array}{l}-0.49 \\
(7.59)\end{array}$ & $\begin{array}{l}0.08 \\
(3.19)\end{array}$ \\
\hline Social security expenditure (H1) & & $\begin{array}{l}1.55^{* *} \\
(0.76)\end{array}$ & $\begin{array}{l}-0.30 \\
(1.53)\end{array}$ & $\begin{array}{l}2.41 * * * \\
(0.89)\end{array}$ & & $\begin{array}{l}-2.20^{* * *} \\
(0.87)\end{array}$ & $\begin{array}{l}- \\
\quad 4.31 *_{-} \\
* * \\
(1.59)\end{array}$ & $\begin{array}{l}-2.31^{* *} \\
(1.02)\end{array}$ \\
\hline Public administration share $(\mathrm{H} 1)$ & & $\begin{array}{l}0.09 \\
(0.43)\end{array}$ & $\begin{array}{l}1.30 \\
(1.21)\end{array}$ & $\begin{array}{l}-0.29 \\
(0.63)\end{array}$ & & $\begin{array}{l}-1.51^{* * * *} \\
(0.48)\end{array}$ & $\begin{array}{l}5.01 *_{-} \\
* * \\
(135)\end{array}$ & $\begin{array}{l}-1.26^{*} \\
(0.71)\end{array}$ \\
\hline & & & -0.06 & $-7.17^{*}$ & & & 0.54 & $18.39 * * *$ \\
\hline
\end{tabular}


Table 3 (continued)

\begin{tabular}{|c|c|c|c|c|c|c|c|c|}
\hline Specification & (1) & (2) & (3) & (4) & (5) & (6) & (7) & (8) \\
\hline $\begin{array}{l}\text { Interaction: safety expenditure } \\
(\mathrm{H} 5 / \mathrm{H} 4)\end{array}$ & & & $(0.33)$ & (4.03) & & & $(0.37)$ & $(6.15)$ \\
\hline $\begin{array}{l}\text { Interaction: economic affairs } \\
\text { expenditure }(\mathrm{H} 5 / \mathrm{H} 4)\end{array}$ & & & $\begin{array}{l}0.02 \\
(0.04)\end{array}$ & $\begin{array}{l}1.31 * * \\
(0.62)\end{array}$ & & & $\begin{array}{l}0.02 \\
(0.05)\end{array}$ & $\begin{array}{l}0.33 \\
(0.63)\end{array}$ \\
\hline $\begin{array}{l}\text { Interaction: housing expenditure } \\
\text { (H5/H4) }\end{array}$ & & & $\begin{array}{c}- \\
0.44- \\
* * \\
(0.19)\end{array}$ & $\begin{array}{l}-1.79 \\
(2.85)\end{array}$ & & & $\begin{array}{l}0.17 \\
(0.21)\end{array}$ & $\begin{array}{l}-3.24 \\
(3.20)\end{array}$ \\
\hline $\begin{array}{l}\text { Interaction: culture expenditure } \\
(\mathrm{H} 5 / \mathrm{H} 4)\end{array}$ & & & $\begin{array}{l}0.30 \\
(0.33)\end{array}$ & $\begin{array}{l}-1.72 \\
(5.06)\end{array}$ & & & $\begin{array}{l}-0.13 \\
(0.37)\end{array}$ & $\begin{array}{l}-1.21 \\
(5.47)\end{array}$ \\
\hline $\begin{array}{l}\text { Interaction: education expenditure } \\
\qquad(\mathrm{H} 5 / \mathrm{H} 4)\end{array}$ & & & $\begin{array}{l}-0.10 \\
(0.16)\end{array}$ & $\begin{array}{l}-1.27 \\
(1.96)\end{array}$ & & & $\begin{array}{l}-0.01 \\
(0.17)\end{array}$ & $\begin{array}{l}-0.04 \\
(2.22)\end{array}$ \\
\hline $\begin{array}{l}\text { Interaction: social security } \\
\text { expenditure }(\mathrm{H} 5 / \mathrm{H} 4)\end{array}$ & & & $\begin{array}{l}0.05 \\
(0.04)\end{array}$ & $\begin{array}{l}1.34 * * * \\
(0.45)\end{array}$ & & & $\begin{array}{l}0.0610 \\
(0.04)\end{array}$ & $\begin{array}{l}-1.04 * * \\
(0.52)\end{array}$ \\
\hline $\begin{array}{l}\text { Interaction: public administration } \\
\text { share }(\mathrm{H} 5 / \mathrm{H} 4)\end{array}$ & & & $\begin{array}{l}-0.02 \\
(0.03)\end{array}$ & $\begin{array}{l}-0.25 \\
(0.43)\end{array}$ & & & $\begin{array}{l}0.11 * * * \\
(0.03)\end{array}$ & $\begin{array}{l}-0.10 \\
(0.48)\end{array}$ \\
\hline Constant & $\begin{array}{l}45.01 * * \\
(19.62)\end{array}$ & $\begin{array}{l}31.35 \\
(40.72)\end{array}$ & $\begin{array}{l}-130.7 \\
(116.15)\end{array}$ & $\begin{array}{l}21.32 \\
(55.67)\end{array}$ & $\begin{array}{l}16.71 \\
(23.22)\end{array}$ & $\begin{array}{l}60.70 \\
(45.46)\end{array}$ & $\begin{array}{l}291.10 * * \\
(127.78)\end{array}$ & $\begin{array}{l}-29.57 \\
(55.99)\end{array}$ \\
\hline $\mathrm{N}$ & 274 & 274 & 274 & 274 & 274 & 274 & 274 & 274 \\
\hline$r^{2}$ within & .17 & .36 & .41 & .42 & .24 & .47 & .53 & .5 \\
\hline$r^{2}$ overall & .12 & .14 & .18 & .05 & .45 & .06 & .01 & .26 \\
\hline$r^{2}$ between & .09 & .23 & .28 & .15 & .45 & .03 & .07 & .20 \\
\hline$F$-stats & 3.42 & 2.83 & 2.50 & 2.60 & 6.25 & 4.85 & 4.33 & 4.36 \\
\hline Loglikelihood & $\begin{array}{l}- \\
795 .- \\
12\end{array}$ & -508.47 & $\begin{array}{l}- \\
500 .- \\
80\end{array}$ & -499.10 & $\begin{array}{l}- \\
\quad 869 .- \\
88\end{array}$ & -556.48 & -545.51 & -545.13 \\
\hline$F$ test for fixed-effects & 7.07 & 5.56 & 4.76 & 4.67 & 6.09 & 6.85 & 5.6 & 5.99 \\
\hline Sigma $u$ & 11.29 & 25.68 & 29.91 & 22.86 & 13.38 & 22.34 & 26.19 & 23.16 \\
\hline Sigma $e$ & 5.06 & 4.69 & 4.65 & 4.61 & 6.14 & 5.43 & 5.29 & 5.27 \\
\hline Rho & .83 & .96 & .97 & .96 & .82 & .94 & .96 & .95 \\
\hline
\end{tabular}

Note: Level of statistical significance $* 0.05 \% ; * * 0.01 \%$, and $* * * 0.001 \%$. Standard errors robust for heteroskedasticity are in parenthesis. Reference year 2005. Reference country = Afghanistan. Number of obs. 272. Number of countries: 52

Source: authors' calculation

hypothesized relationship. Safety expenditure reduces necessity entrepreneurship $(\beta=-7.17, p<$ 0.01 ) (spec. 4, Table 3 ) and increases opportunity entrepreneurship $(\beta=18.39, p<0.01)$ (spec. 8, Table 3). The evidence for $\mathrm{H} 5$ is mixed and demonstrates that not all government expenditure has a ubiquitous effect on the type of entrepreneurship activity.

Overall, our findings illustrate the importance of considering the heterogeneity of entrepreneurship. We find mixed support for all our hypotheses.

The results for our control variables are as follows. Economic development proxied by "rich" is not associated with necessity and opportunity entrepreneurship, highlighting that both types of entrepreneurs can exist in countries with different levels of economic development. The private credit bureau is negatively associated with necessity entrepreneurship but positively with opportunity. A share of the population with tertiary education increases opportunity entrepreneurship and is not associated with necessity entrepreneurship. Government support has no direct effect on the type of entrepreneurship activity, while the effect changes when we control for interaction effects. We find that unemployment is negatively associated with opportunity entrepreneurship (spec. 6, Table 3) and is not associated with necessity entrepreneurship (spec. 2, Table 3). 


\section{Discussion and conclusion}

Entrepreneurship activity is vital for economic development, so policymakers and scholars are interested in determining components that positively influence these activities and understanding entrepreneurial motivation to enter the market. This paper has examined how tax policies, government size, and corruption influence necessity and opportunity entrepreneurship. We use a 2005-2015 country-level panel data matching five distinctive datasets for 52 countries and show that a high corruption and tax will negatively affect both types of entrepreneurs, while government size effect on necessity and opportunity is distinctive and conditional on different types of government expenditures. Our results suggest that different types of entrepreneurship require different types of policies. Not all kinds of entrepreneurship contribute equally to society or in the same way (Block \& Sandner, 2009; Reynolds et al., 2005; Vivarelli, 2004; Vivarelli, 2013) and policy makers can consider how to support the type of entrepreneurship they want to prioritize. Our empirical approach enables us to provide detailed new insights. This approach is appropriate for research on the complex institutional environment when one-size-fits-all government expenditure is not enough (Levie \& Autio, 2011).

Our results suggest that the impact of the same institutional settings (corruption) on necessity and opportunity entrepreneurship is not uniform (see Levie \& Autio, 2011) as the size of the effect varies between types of government expenditure. Additionally, while corruptionmay not discourage a share of necessity entrepreneurs, the overall resultremains negative. Entrepreneurs are constantly engaging in activities to help their ventures and in some cases may seek to leverage corruption to their advantage, but boththe necessity and opportunity entrepreneurs are adversely affected by corruption.

When it comes to the interaction effect of corruption and government size on opportunity and necessity entrepreneurship as the direction of the relationship depends on the type of government expenditure (i.e., safety, economic affairs, housing, education, social security, public administration). Our results indicate that investing in economic affairs and increasing social security can support necessity entrepreneurs, andsafety expenditure can supportopportunity entrepreneurs. We are not able to test if there is a shift or transition between people who become necessity and opportunity entrepreneurship when government spending changes. Our study results also reveal that, in many cases, the effects of taxes and corruption in combination with heterogeneous government expenditure are not the same for opportunity and necessity entrepreneurship. For taxes and corruption, the effect depends on what government invests in and whether it targets to increase the supply of entrepreneursor increase the demand for entrepreneurs. To increase entrepreneurial activity in a country, government plays an important role. However, government investment may have a different effect on necessity entrepreneurs and opportunity entrepreneurs, who may also leverage the government's services differently.

\subsection{Study limitations and future research}

While we included time lags in our model, there may be an endogeneity between government size, corruption, and entrepreneurship activity which in the future research may require instruments and longitudinal data with longer lags for robustness check. The GEM entrepreneurship-related measures also have their limitations, notably the entrepreneurship measures' low comparability between developed and developing countries (Reynolds et al., 2002). It should be noted that we controlled for time-invariant systematic measurement errors using country-level fixed-effects, which helps reduce concerns about these measurements.

We provide fresh empirical insights to the importance of considering heterogeneous institutions and heterogeneous entrepreneurship outcomes. We add to recent studies that found institutional conditions can play a role in shaping the nature and quality of entrepreneurship activity. Chowdhury et al. (2019) and Sutter et al. (2017), for instance, assert that regulation matters for net entrepreneurship productivity score, and it can play a role in shaping cognitive and informal economy dimensions. Future research can examine how policymakers can formulate policies to target specific types of entrepreneurship outcomes that are salient in their contexts, for example if they wanted to support more opportunity entrepreneurs. 


\section{Appendix}

Table 4 List of countries included in the study

\begin{tabular}{|c|c|c|c|c|c|}
\hline Country & Obs. & Country & Obs. & Country & Obs. \\
\hline Algeria & 3 & Indonesia & 5 & Portugal & 5 \\
\hline Argentina & 7 & Ireland & 7 & Romania & 5 \\
\hline Australia & 7 & Israel & 5 & Russian Federation & 6 \\
\hline Belgium & 7 & Italy & 7 & Serbia & 3 \\
\hline Bosnia and Herzegovina & 4 & Jamaica & 6 & Slovak Republic & 2 \\
\hline Brazil & 5 & Japan & 6 & Slovenia & 7 \\
\hline Chile & 7 & Kazakhstan & 2 & Spain & 7 \\
\hline Colombia & 6 & Korea, Rep. & 2 & Sweden & 7 \\
\hline Costa Rica & 2 & Latvia & 7 & Switzerland & 7 \\
\hline Croatia & 7 & Macedonia, FYR & 3 & Thailand & 7 \\
\hline Czech Republic & 6 & Malaysia & 6 & Tunisia & 3 \\
\hline Denmark & 7 & Mexico & 7 & Turkey & 6 \\
\hline Egypt, Arab Rep. & 2 & Morocco & 2 & Uganda & 2 \\
\hline Greece & 3 & Netherlands & 7 & United Arab Emirates & 5 \\
\hline Hong Kong SAR, China & 6 & Norway & 7 & United Kingdom & 7 \\
\hline Hungary & 7 & Panama & 3 & Uruguay & 5 \\
\hline Iceland & 7 & Peru & 3 & & \\
\hline India & 6 & Philippines & 4 & & \\
\hline
\end{tabular}

Acknowledgements Farzana Chowdhury would like to thank her dissertation committee members for advice. We would like to thank the editor and reviewer for their time and guidance. We also thank Johan Eklund, Magnus Henrekson, participants at the 2014 ZEW conference on national systems of entrepreneurship, and 2015 Babson College Entrepreneurship Research Conference participants for comments.

\section{References}

Acemoglu, D. (2005). Politics and economics in weak and strong states. Journal of Monetary Economics, 52(7), 1199-1226. https://doi.org/10.1016/j.jmoneco.2005.05.001.

Acs, Z. J., Desai, S., \& Hessels, J. (2008). Entrepreneurship, economic development and institutions. Small Business Economics, 31(3), 219-234. https://doi.org/10.1007 /s11187-008-9135-9.

Afonso, A., Schuknecht, L., \& Tanzi, V. (2005). Public sector efficiency: An international comparison. Public Choice, 123(3-4), 321-347. https://doi.org/10.1007/s11127-0057165-2.

Agwu, P. E., Onwuegbuzie, H. N., \& Ezeifeka, P. (2017). Impact of entrepreneurship education on new ventures creation-A case study. Advances in Social Sciences Research Journal, 4(25). https://doi.org/10.14738/assrj.425.4014.

Aidis, R., Estrin, S., \& Mickiewicz, T. M. (2012). Size matters: Entrepreneurial entry and government. Small Business Economics, 39(1), 119-139. https://doi.org/10.1007 /s11187-010-9299-y.

Alesina, A., \& Angeletos, G. M. (2005). Corruption, inequality, and fairness. Journal of Monetary Economics, 52(7), 12271244. https://doi.org/10.1016/j.jmoneco.2005.05.003.

Alesina, A., Di Tella, R., \& MacCulloch, R. (2004). Inequality and happiness: Are Europeans and Americans different? Journal of Public Economics, 88(9-10), 2009-2042. https://doi. org/10.1016/j.jpubeco.2003.07.006.

Amorós, J. E., Ciravegna, L., Mandakovic, V., \& Stenholm, P. (2019). Necessity or opportunity? The effects of state fragility and economic development on entrepreneurial efforts. Entrepreneurship Theory and Practice, 43(4), 725-750. https://doi.org/10.1177/1042258717736857.

Angrist, J. D., \& Pischke, J. S. (2008). Mostly harmless econometrics: An empiricist's companion. Princeton university press.

Anokhin, S., \& Schulze, W. S. (2009). Entrepreneurship, innovation, and corruption. Journal of Business Venturing, 24(5), 465-476. https://doi.org/10.1016/j.jbusvent.2008.06.001. 
Asimakopoulos, S., \& Karavias, Y. (2016). The impact of government size on economic growth: A threshold analysis. Economics Letters, 139, 65-68. https://doi.org/10.1016/j. econlet.2015.12.010.

Audretsch, D. B., \& Lehmann, E. E. (2017). Economic performance and the knowledge spillover theory of entrepreneurship: A comment. The Journal of Technology Transfer, 42(5), 1234-1235. https://doi.org/10.1007/s10961-0169507-2.

Audretsch, D. B., Keilbach, M. C., \& Lehmann, E. E. (2006). Entrepreneurship and economic growth. Oxford University Press.

Audretsch, D. B., Heger, D., \& Veith, T. (2015). Infrastructure and entrepreneurship. Small Business Economics, 44(2), 219230. https://doi.org/10.1007/s11187-014-9600-6.

Audretsch, D. B., Lehmann, E. E., Menter, M., \& Seitz, N. (2019a). Public cluster policy and firm performance: Evaluating spillover effects across industries. Entrepreneurship and Regional Development, 31(1-2), 150-165. https://doi.org/10.1080/08985626.2018.1537153.

Audretsch, D. B., Belitski, M., \& Desai, S. (2019b). National business regulations and city entrepreneurship in Europe: A multilevel nested analysis. Entrepreneurship Theory and Practice, 43(6), 1148-1165. https://doi.org/10.1177 $/ 1042258718774916$.

Audretsch, D. B., Belitski, M., \& Cherkas, N. (2021). Entrepreneurial ecosystems in cities: The role of institutions. PLoS ONE, 16(3), e0247609. https://doi.org/10.1371 /journal.pone.0247609.

Barro, R. J. (1990). Government spending in a simple model of endogenous growth. Journal of Political Economy, 98(5, Part 2), S103-S125.

Baum, C. F., Lööf, H., Nabavi, P., \& Stephan, A. (2017). A new approach to estimation of the R\&D-innovation-productivity relationship. Economics of Innovation and New Technology, 26(1-2), 121-133. https://doi.org/10.1080 $/ 10438599.2016 .1202515$.

Baumol, W. J. (1990). Entrepreneurship: Productive, unproductive, and destructive. Journal of Political Economy, 98, 893$92 \mathrm{I}$.

Baumol, W. J., \& Strom, R. J. (2007). Entrepreneurship and economic growth. Strategic Entrepreneurship Journal, 1(34), 233-237. https://doi.org/10.1002/sej.26.

Belda, P. R., \& Cabrer-Borrás, B. (2018). Necessity and opportunity entrepreneurs: Survival factors. International Entrepreneurship and Management Journal, 14(2), 249264. https://doi.org/10.1007/s11365-018-0504-9.

Belitski, M., Chowdhury, F., \& Desai, S. (2016). Taxes, corruption, and entry. Small Business Economics, 47(1), 201-216. https://doi.org/10.1007/s11187-016-9724-y.

Bergh, A., \& Henrekson, M. (2011). Government size and growth: A survey and interpretation of the evidence. Journal of Economic Surveys, 25(5), 872-897. https://doi.org/10.1111 j.1467-6419.2011.00697.x.

Berry, W. D., \& Lowery, D. (1987). Understanding United States government growth: An empirical analysis of the postwar era. Greenwood Publishing Group.

Blackburn, K., \& Forgues-Puccio, G. F. (2007). Distribution and development in a model of misgovernance. European Economic Review, 51(6), 1534-1563. https://doi. org/10.1016/j.euroecorev.2006.10.003.
Block, J., \& Sandner, P. (2009). Necessity and opportunity entrepreneurs and their duration in self-employment: Evidence from German micro data. Journal of Industry, Competition and Trade, 9(2), 117-137. https://doi.org/10.1007/s10842007-0029-3.

Block, J. H., Kohn, K., Miller, D., \& Ullrich, K. (2015). Necessity entrepreneurship and competitive strategy. Small Business Economics, 44(1), 37-54. https://doi.org/10.1007/s11187014-9589-x.

Braunerhjelm, P., Eklund, J., \& Thulin, P. (2021). Taxes, the tax administrative burden and the entrepreneurial life cycle. Small Business Economics, 56(2), 681-694.

Bruce, D., \& Schuetze, H. J. (2004). Tax policy and entrepreneurship. Swedish Economic Policy Review, 11(2), 233-265.

Bruton, G. D., Ahlstrom, D., \& Li, H. L. (2010). Institutional theory and entrepreneurship: Where are we now and where do we need to move in the future? Entrepreneurship Theory and Practice, 34(3), 421-440. https://doi.org/10.1111 j.1540-6520.2010.00390.x.

Choi, J. P., \& Thum, M. (2005). Corruption and the shadow economy. International Economic Review, 46(3), 817-836. https://doi.org/10.1111/j.1468-2354.2005.00347.x.

Chowdhury, F., Audretsch, D. B., \& Belitski, M. (2019). Institutions and entrepreneurship quality. Entrepreneurship Theory and Practice, 43(1), 51-81. https://doi.org/10.1177 /1042258718780431.

Cooper, A. (2003). Entrepreneurship: The past, the present, the future. In Handbook of entrepreneurship research (pp. 2134). Springer, Boston, MA.

Cullen, J. B., \& Gordon, R. H. (2007). Taxes and entrepreneurial risk-taking: Theory and evidence for the US. Journal of Public Economics, 91(7-8), 1479-1505. https://doi. org/10.1016/j.jpubeco.2006.12.001.

Cumming, D., Johan, S., \& Zhang, Y. (2018). Public policy towards entrepreneurial finance: Spillovers and the scale-up gap. Oxford Review of Economic Policy, 34(4), 652-675. https://doi.org/10.1093/oxrep/gry012.

Desai, S., Acs, Z. J., \& Weitzel, U. (2013). A model of destructive entrepreneurship: Insight for conflict and postconflict recovery. Journal of Conflict Resolution, 57(1), 20-40. https://doi. org/10.1177/0022002712464853.

Djankov, S., La Porta, R., Lopez-de-Silanes, F., \& Shleifer, A. (2002). The regulation of entry. The Quarterly Journal of Economics, 117(1), 1-37. https://doi.org/10.1162 /003355302753399436.

Djankov, S., Ganser, T., McLiesh, C., Ramalho, R., \& Shleifer, A. (2010). The effect of corporate taxes on investment and entrepreneurship. American Economic Journal: Macroeconomics, 2(3), 31-64. https://doi.org/10.1257 /mac.2.3.31.

Domar, E. D., \& Musgrave, R. A. (1944). Proportional income taxation and risk-taking. The Quarterly Journal of Economics, 58(3), 388-422. https://doi.org/10.2307 $/ 1882847$.

Dreher, A., \& Gassebner, M. (2013). Greasing the wheels? The impact of regulations and corruption on firm entry. Public Choice, 155(3-4), 413-432. https://doi.org/10.1007/s11127011-9871-2.

Edelman, L., \& Yli-Renko, H. (2010). The impact of environment and entrepreneurial perceptions on venture-creation efforts: Bridging the discovery and creation views of 
entrepreneurship. Entrepreneurship Theory and Practice, 34(5), 833-856. https://doi.org/10.1111/j.15406520.2010.00395.x.

Estrin, S., Korosteleva, J., \& Mickiewicz, T. (2013). Which institutions encourage entrepreneurial growth aspirations? Journal of Business Venturing, 28(4), 564-580. https://oi. org/10.1016/j.jbusvent.2012.05.001.

Fadahunsi, A., \& Rosa, P. (2002). Entrepreneurship and illegality: Insights from the Nigerian cross-border trade. Journal of Business Venturing, 17(5), 397-429. https://doi.org/10.1016 /S0883-9026(01)00073-8.

Fairlie, R. (2011). Kauffman index of entrepreneurial activity 1999-2010, available at SSRN 1780284.

Fairlie, R. W., Kapur, K., \& Gates, S. (2011). Is employer-based health insurance a barrier to entrepreneurship? Journal of Health Economics, 30(1), 146-162. https://doi.org/10.1016 /j.jhealeco.2010.09.003.

Fan, C. S., Lin, C., \& Treisman, D. (2009). Political decentralization and corruption: Evidence from around the world. Journal of Public Economics, 93(1-2), 14-34. https://doi. org/10.1016/j.jpubeco.2008.09.001.

Fisman, R., \& Gatti, R. (2002). Decentralization and corruption: Evidence from US federal transfer programs. Public Choice, 113(1-2), 25-35. https://doi.org/10.1023/A:1020311511787.

Fossen, F. M., \& König, J. (2017). Public health insurance, individual health, and entry into self-employment. Small Business Economics, 49(3), 647-669. https://doi. org/10.1007/s11187-017-9843-0.

Fredström, A., Peltonen, J., \& Wincent, J. (2020). A country-level institutional perspective on entrepreneurship productivity: The effects of informal economy and regulation. Journal of Business Venturing, 106002. https://doi.org/10.1016/j. jbusvent.2020.106002.

Friedman, E., Johnson, S., Kaufmann, D., \& Zoido-Lobaton, P. (2000). Dodging the grabbing hand: The determinants of unofficial activity in 69 countries. Journal of Public Economics, 76(3), 459-493. https://doi.org/10.1016/S00472727(99)00093-6.

Goedhuys, M., \& Sleuwaegen, L. (2010). High-growth entrepreneurial firms in Africa: A quantile regression approach. Small Business Economics, 34(1), 31-51. https://doi.org/10.1007 /s11187-009-9193-7.

Hammar, H., Jagers, S. C., \& Nordblom, K. (2009). Perceived tax evasion and the importance of trust. The Journal of SocioEconomics, 38(2), 238-245. https://doi.org/10.1016/j. socec.2008.07.003.

Hauner, D., \& Kyobe, A. (2010). Determinants of government efficiency. World Development, 38(11), 1527-1542. https://doi.org/10.1016/j.worlddev.2010.04.004.

Hechavarria, D. M., \& Reynolds, P. D. (2009). Cultural norms \& business start-ups: The impact of national values on opportunity and necessity entrepreneurs. International Entrepreneurship and Management Journal, 5(4), 417437. https://doi.org/10.1007/s11365-009-0115-6.

Heinemann, F. (2008). Is the welfare state self-destructive? A study of government benefit morale. Kyklos, 61(2), 237257. https://doi.org/10.1111/j.1467-6435.2008.00400.x.

Henrekson, M. (2005). Entrepreneurship: A weak link in the welfare state? Industrial and Corporate Change, 14(3), 437-467. https://doi.org/10.1093/icc/dth060.
Henrekson, M., Johansson, D., \& Stenkula, M. (2010). Taxation, labor market policy and high-impact entrepreneurship, Journal of Industry. Competition and Trade, 10(3-4), 275296. https://doi.org/10.1007/s10842-010-0081-2.

Holtz-Eakin, D., Penrod, J. R., \& Rosen, H. S. (1996). Health insurance and the supply of entrepreneurs. Journal of Public Economics, 62(1-2), 209-235. https://doi.org/10.1016/00472727(96)01579-4.

Kaufmann D, Kraay A, \& Mastruzzi M. (2009). Governance matters VIII: Aggregate and individual governance indicators 1996-2008, The World Bank. World Bank policy research working paper, 4978.

Laffineur, C., Barbosa, S. D., Fayolle, A., \& Nziali, E. (2017). Active labor market programs' effects on entrepreneurship and unemployment. Small Business Economics, 49(4), 889918. https://doi.org/10.1007/s11187-017-9857-7.

Lerner, J., \& Kegler, C. (2000). Evaluating the small business innovation research program: A literature review. The small business innovation research program: An assessment of the department of defense fast track initiative, 307-324.

Levie, J., \& Autio, E. (2011). Regulatory burden, rule of law, and entry of strategic entrepreneurs: An international panel study. Journal of Management Studies, 48(6), 1392-1419. https://doi.org/10.1111/j.1467-6486.2010.01006.x.

Lofstrom, M. (2013). Does self-employment increase the economic well-being of low-skilled workers? Small Business Economics, 40(4), 933-952. https://doi.org/10.1007 /s11187-011-9402-z.

Marvel, M. R., Davis, J. L., \& Sproul, C. R. (2016). Human capital and entrepreneurship research: A critical review and future directions. Entrepreneurship Theory and Practice, 40(3), 599-626. https://doi.org/10.1111/etap.12136.

Mauro, P. (1995). Corruption and growth. The Quarterly Journal of Economics, 110(3), 681-712.

Mauro, P. (1998). Corruption and the composition of government expenditure. Journal of Public Economics, 69(2), 263-279. https://doi.org/10.1016/S0047-2727(98)00025-5.

Méon, P. G., \& Sekkat, K. (2005). Does corruption grease or sand the wheels of growth? Public Choice, 122(1-2), 69-97.

Méon, P. G., \& Weill, L. (2010). Is corruption an efficient grease? World Development, 38(3), 244-259. https://doi.org/10.1016 /j.worlddev.2009.06.004.

Mueller, D. C. (2004). Public choice: An introduction. In The encyclopedia of public choice (pp. 32-48). Springer.

Musgrave, R. A. (1959). The theory of public finance. McGraw Hill.

Nikolaev, B. N., Boudreaux, C. J., \& Palich, L. (2018). Crosscountry determinants of early-stage necessity and opportunity-motivated entrepreneurship: Accounting for model uncertainty. Journal of Small Business Management, 56(sup1), 243-280. https://doi.org/10.1111/jsbm.12400.

Nyström, K. (2008). The institutions of economic freedom and entrepreneurship: Evidence from panel data. Public Choice, 136(3-4), 269-282. https://doi.org/10.1007/s11127-0089295-9.

O'Higgins, E. R. (2006). Corruption, underdevelopment, and extractive resource industries: Addressing the vicious cycle. Business Ethics Quarterly, 16(2), 235-254.

Pandey, P. (2010). Service delivery and corruption in public services: How does history matter? American Economic 
Journal: Applied Economics, 2(3), 190-204. https://doi. org/10.1257/app.2.3.190.

Parker, S. C. (2004). The economics of self-employment and entrepreneurship. Cambridge university press.

Parker, S. (2018). The economics of entrepreneurship. Cambridge University Press.

Peltzman, S. (1976). Toward a more general theory of regulation. The Journal of Law and Economics, 19(2), 211-240.

Pfeffer, J., \& Salancik, G. R. (1978). The external control of organizations: A resource dependence perspective. Harper and Row.

Pigou, A. C. (1928). An analysis of supply. The Economic Journal, 38(150), 238-257.

Reynolds, P. D., Bygrave, W. D., Autio, E., Cox, L. W., \& Hay, M. (2002). Global entrepreneurship monitor, 2002 executive report. Babson College.

Reynolds, P., Bosma, N., Autio, E., Hunt, S., De Bono, N., Servais, I., et al. (2005). Global entrepreneurship monitor: Data collection design and implementation 1998-2003. Small Business Economics, 24(3), 205-231.

Roodman, D. (2011). Fitting fully observed recursive mixedprocess model with cmp. STATA Journal, 11(2), 159-206.

Rose-Ackerman, S. (1999). Corruption and government: Causes, consequences, and reform. Cambridge university press.

Rose-Ackerman, S. (Ed.). (2007). International handbook on the economics of corruption. Edward Elgar Publishing.

Scholz, J. T., \& Lubell, M. (1998). Trust and taxpaying: Testing the heuristic approach to collective action. American Journal of Political Science, 398-417.

Shiller, R. J. (2017). Narrative economics. American Economic Review, 107(4), 967-1004.

Shleifer, A., \& Vishny, R. W. (2002). The grabbing hand: Government pathologies and their cures. Harvard University Press.

Stenholm, P., Acs, Z. J., \& Wuebker, R. (2013). Exploring country-level institutional arrangements on the rate and type of entrepreneurial activity. Journal of Business Venturing, 28(1), 176-193. https://doi.org/10.1016/j. jbusvent.2011.11.002.

Sutter, C., Webb, J., Kistruck, G., Ketchen Jr., D. J., \& Ireland, R. D. (2017). Transitioning entrepreneurs from informal to formal markets. Journal of Business Venturing, 32(4), 420-442. https://doi.org/10.1016/j.jbusvent.2017.03.002.

Tanzi, V., \& Schuknecht, L. (2000). Public spending in the 20th century: A global perspective. Cambridge University Press.

Tonoyan, V., Strohmeyer, R., Habib, M., \& Perlitz, M. (2010). Corruption and entrepreneurship: How formal and informal institutions shape small firm behavior in transition and mature market economies. Entrepreneurship Theory and Practice, 34(5), 803-832. https://doi.org/10.1111/j.15406520.2010.00394.x.

Torgler, B. (2003). Tax morale, rule-governed behaviour and trust. Constitutional Political Economy, 14(2), 119-140. https://doi.org/10.1023/A:1023643622283.

Tullock, G. (1967). The welfare costs of tariffs, monopolies, and theft. Economic Inquiry, 5(3), 224-232.

Tybout, J. R. (2000). Manufacturing firms in developing countries: How well do they do, and why? Journal of Economic Literature, 38(1), 11-44. https://doi.org/10.1257/jel.38.1.11.

van der Zwan, P., Thurik, R., Verheul, I., \& Hessels, J. (2016). Factors influencing the entrepreneurial engagement of opportunity and necessity entrepreneurs. Eurasian Business Review, 6(3), 273-295. https://doi.org/10.1007/s40821-0160065-1.

Vivarelli, M. (2004). Are all the potential entrepreneurs so good? Small Business Economics, 23(1), 41-49. https://doi. org/10.1023/B:SBEJ.0000026023.11752.a9.

Vivarelli, M. (2013). Is entrepreneurship necessarily good? Microeconomic evidence from developed and developing countries. Industrial and Corporate Change, 22(6), 14531495. https://doi.org/10.1093/icc/dtt005.

Welter, F., Baker, T., \& Wirsching, K. (2019). Three waves and counting: The rising tide of contextualization in entrepreneurship research. Small Business Economics, 52(2), 319-330. https://doi.org/10.1007/s11187-018-0094-5.

Wennekers, S., Van Wennekers, A., Thurik, R., \& Reynolds, P. (2005). Nascent entrepreneurship and the level of economic development. Small Business Economics, 24(3), 293-309. https://doi.org/10.1007/s11187-005-1994-8.

Williamson, O. E. (2000). The new institutional economics: Taking stock, looking ahead. Journal of Economic Literature, 38(3), 595-613. https://doi.org/10.1257 /jel.38.3.595.

World Bank. (2004). Doing business in 2004: Understanding regulation. World Bank.

World Bank. (2007). Doing business in 2007: How to reform. World Bank.

Zellner, A. (1962). An efficient method of estimating seemingly unrelated regressions and tests for aggregation bias. Journal of the American Statistical Association, 57(298), 348-368.

Publisher's note Springer Nature remains neutral with regard to jurisdictional claims in published maps and institutional affiliations. 